\title{
Comparative Study on Anti Diabetic Property of Syzyium cumini, Aegle marmelos and Cocos nucifera through in vitro and in vivo Condition
}

\author{
Mani Priya .B ${ }^{1}$, Subha Ranjani . $S^{2}$ \\ ${ }^{1}$ BSc Microbiology, Department of Microbiology, The Standard fireworks Rajaratnam College for women, Sivakasi \\ ${ }^{2}$ Assistant Professor, Department of Microbiology, The Standard fireworks Rajaratnam College for women, Sivakasi
}

\begin{abstract}
The aim of the present study was to investigate presence of antidiabetic activity in plant extracts like Syzyium cumini, Aegle marmelos and Cocos nucifera using a solvent like methanol and aqueous. In preliminary phytochemical analysis and Paper Chromotography, different types of phytocompounds like alkaloids, flavonoids, phenols, glycosides and saponins were present, which it had been concluded that there is rich in phyto compounds for the antidiabetic activity which is highly responsible for regulating the pancreatic hormone for the synthesis of insulin. In the in vitro antidiabetic analysis, among all the three plant extracts, aqueous extract of Cocos nucifera have high sugar reducing capacity. Aqueous extract of Cocos nucifera were taken for HPLC analysis and antioxidant activity. HPLC analysis of Cocos nucifera resulted in attaining a sharp peak with retention time of 1.983. It was closely related to stevioside compounds. Analysis of antioxidant activity in Cocos nucifera shows $69.8 \%$ of reductions in DPPH free radicals for $100 \mu \mathrm{g} / \mathrm{ml}$. Aqueous extract of Cocos nucifera were further taken for in vivo study. The mice were made diabetic by intraperitoneal administration of $150 \mathrm{mg} / \mathrm{kg}$ of alloxan. Finally, blood sugar reduces from $408 \mathrm{mg} / \mathrm{dl}$ to $88 \mathrm{mg} / \mathrm{dl}$ when treated with endocarpic extract of coconut.
\end{abstract}

Keywords: Cocos nucifera, antidiabetic, HPLC, alloxan, Intraperitoneal

\section{Introduction}

Diabetes mellitus (DM) is a complex and a diverse group of disorders that disturbs the metabolism of carbohydrate, fat and protein. The number of diabetes mellitus cases has been increasing worldwide in recent years. In 2000, the World Health Organization estimated a total of 171 million of people with diabetes mellitus from the global population, and this report projected to increase to 366 million by 2030 . Diabetes is becoming the third killer of mankind, after cancer and cardiovascular disease, because of its high prevalence, morbidity and mortality. The number of adults suffering from diabetes in India is expected to increase three fold, from 19.4 million in 1995 and 57.2 million in 2025[1].

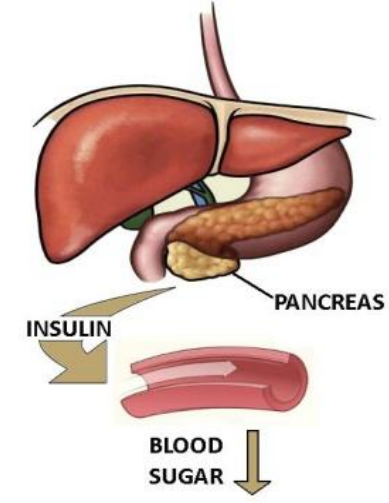

Figure 1: Role of insulin

Diabetes mellitus (DM), commonly referred to as diabetes, is a group of metabolic diseases in which there are high blood sugarlevels over a prolonged period. Insulin is an only growth harmone that could regulate the blood sugar level in the body as mentioned by fig: 1 .
At present the treatment of diabetes mellitus is based on oral hypoglycemic agent and insulin. An almost artificially synthesized drug brings out some side effects. Human beings have to depend on nature since his existence for survival. Using his knowledge man has discovered many remedies for ailments from nature such as plants, mineral materials and animal products [2]. The history of drug is intimately linked with plants from the earliest times and even today plant products have extensive use in ethno medicine, traditional systems of medicines as well as in the armamentarium of the modern physician. The interest in the study of medicinal plants as a source of pharmacologically active compounds has increased worldwide. It is recognized that in developing countries like India, plants are the main medicinal source to treat infectious diseases [3]

Diabetes mellitus (DM) is also treated by Indian traditional medicine using anti-diabetic medicinal plants. However, herbs are not inexhaustible natural resources and the demand for herbal medicines can't be met by cultivation. With a long course and serious complications often resulting in high death-rate, the treatment of diabetes spent vast amount of resources including medicines, dietary guidelines, physical training and so on in all countries. Thus searching for a new class of compounds is essential to overcome diabetic problems. There is continuous search for alternative drugs because the existing synthetic drugs have several limitations. Many oral hypoglycemic agents like Sulphonylurea, liguanides, thiaolidivediones, meglitinide derivatives and $\alpha$ glucosidase inhibitors are presently in use but they all have several side effects. The herbal drugs with anti diabetic activity are yet to be commercially formulated as modern medicines, even though they have been acclaimed for their therapeutic properties in the traditional systems of medicine. [4] 


\section{International Journal of Science and Research (IJSR) \\ ISSN (Online): 2319-7064}

Index Copernicus Value (2015): 78.96 | Impact Factor (2015): 6.391

The endocrine pancreas consists of approximately 1 million islets of Langerhans interspersed throughout the pancreatic gland. Within the islets, at least four hormone-producing cells are present. Their hormone products include insulin, islet amyloid polypeptide (IAPP, or amylin), whose metabolic function remains undefined glucagon, the hyperglycemic factor that mobilizes glycogen stores; somatostatin, a universal inhibitor of secretory cells, and pancreatic peptide enzyme, a small protein that facilitates digestive processes by a mechanism not yet clarified.

The ethanobotanical information reports about 800 plants that may possess anti diabetic potential. Syzyium cumini (or) Eugenia Jambolona tree belongs to the Myrtaceae family. This is also called as Jamun and Jambul in India and Malaya. It is one of the most commonly medicinal plants used to treat diabetes mellitus in Brazil. Different parts of this plant, such as seeds, bark, fruit and leaves have been used in traditional medicine as a remedy for diabetes mellitus in many country. The seeds are sweet, astringent to bowels and good for diabetes [8]

Aegle marmelos (L) Core, (Rutaceae) is a popular medicinal plant in the Ayurvedic and siddha systems of medicines used to treat a wide variety of ailments. The plant, popularly known as the bale tree, is native to the Indo-Malayan region and is currently cultivated in India, Pakistan, Bangladesh, Srilanka, Burma and Thailand [9].The folkloric use of this species to treat infectious diseases stimulated in human body. It is a large ever green tree upto $30 \mathrm{~m}$ height, the leaves measuring about 10 to $15 \mathrm{~cm}$ long and 4 to $6 \mathrm{~cm}$ wide. The leaf of Aegle marmelos is used for ophthalmic, diabetes and asthmatic complaints. It enhances the ability to utilize the external glucose load in the body by stimulation of glucose uptake similar to insulin [10].

Cocos nucifera is an important member of the family Araceae (palin family) and it is the only accepted species of the genus cocos. The English name is coconut. It has a long history of use in traditional medicine for the treatment of metabolic disorders. The most interesting feature of the fruit is its wall. The fruit wall comprises of three layers exocarp, mesocarp and endocarp. Endocarpic extract of tender coconut act as antidiabetic agent [5]

By chromatographic methods coupled to mass spectrometry techniques, it has been demonstrated that aqueous Cocos nucifera extracts are mainly composed of catechinand alkaloids. These classes of molecules have been associated with analgesic, antidiabetic and antioxidant in several experimental models. The present study compares the methanol and aqueous of the three plants extracts by their phytochemical (Tube test, TLC and HPLC), anti oxidant, anti bacterial and anti diabetic property through In vitro condition and the plant with best glucose degrader were taken for in vivo condition. [7]

\section{Materials and Methods}

\subsubsection{Collection of plant material}

The leaves of Aegle marmelos, Syzium cumini and Cocos nucifera were collected from sadhuragiri hills at Western
Ghats. The plant parts were washed with distilled water. Washed plant leaves of bael and jambul were air dried in darkness at room temperature for 4 days. Endocarpic tender coconut was freshly taken without dryness. Dried and undried plant parts were powdered using a mechanical mixer. [8]

\subsubsection{Plant extraction:}

$10 \mathrm{gm}$ powdered leaves of Aegle marmelos, Syzyium cumini and endocarpic membrane of tender coconut were extracted by using macerate technique. [6]

\subsection{Identification of the Plant Constituents by Phytochemical Test:}

Small quantity of aqueous and methanolic extracts of Aegle marmelos, Syzyium cumini and Cocos nucifera were taken and are used for detection of phytochemical study.[5]

\subsection{Analysis of phyto compounds in paper chromatography:}

Phyto compounds were analysed in paper chromatography, Few drops of aqueous and methanolic extract of the three plant extracts were spotted on the line of paper with the help of capillary tube. The paper was placed the developing jar with mobile phase.

The RF values were calculated by the formula,

Retention factor $(\mathrm{RF})=$

Distance travelled by solvent from origin

Distance travelled by solute from origin

\subsection{Phyto chemical analysis of Cocos nucifera extract by HPLC (High Performance Liquid Chromotography)}

HPLC of crude aqueous extract of Cocos nucifera plant was carried out by SHIMADZU, LC-10AT VP $(25 \mathrm{X} 0.5 \mathrm{~cm}$ 10A) columns. Mobile phase used was Acetonitrile and Phosphate Buffer (35:65). $20 \mu \mathrm{l}$ of the volume was injected with the flow rate of $1 \mathrm{ml} / \mathrm{min}$. Detection wavelength was $268 \mathrm{~nm}$ and the method was carried out at ambient temperature. Isocratic method was used for obtaining chromatogram of metabolites of Cocos nucifera.

\subsection{Determination of anti-oxidant activity}

\section{DPPH radical scavenging activity}

Aqueous extract of Cocos nucifera was used to assess the in vitro antioxidant activity. Antioxidant scavenging activity was studied using 1,1-diphenyl, 2-picryl hydroxyl free radical (DPPH). The DPPH free radical scavenging activity was calculated using the following formula:

$\%$ scavenging $=[$ Absorbance of control - Absorbance of test sample/Absorbance of control] $\times 100$

\subsection{Anti diabetic activity:(in vitro)}

\subsubsection{Preparation of test solution}

Glucose stock was prepared in the concentration of $1 \mathrm{mg} / \mathrm{ml}$. $5 \mathrm{ml}$ and $10 \mathrm{ml}$ of extracts were taken for sugar degradation. $2 \mathrm{ml}$ of glucose stock solution was added to all the extract 


\section{International Journal of Science and Research (IJSR) \\ ISSN (Online): 2319-7064 \\ Index Copernicus Value (2015): 78.96 | Impact Factor (2015): 6.391}

concentrations. These tests were done in triplicates. The test solutions were incubated at room temperature for five days.

\subsubsection{Preparation of anthrone reagent}

$200 \mathrm{mg}$ of anthrone powder were dissolved in $5 \mathrm{ml}$ ethanol and are added with $75 \mathrm{ml}$ of ice cold $95 \% \mathrm{H}_{2} \mathrm{SO}_{4}$.

\subsubsection{Spectrophotometric analysis}

$1 \mathrm{ml}$ of all the test sample was taken along with addition of $5 \mathrm{ml}$ anthrone reagent. The mixtures were kept for incubation in water bath for $10 \mathrm{~min}$ at $45-50^{\circ} \mathrm{C}$. Then $3 \mathrm{ml}$ of mixture solution were taken in the cuvette tubes for absorbency reading at $625 \mathrm{~nm}$, against blank solution $(1 \mathrm{ml}$ of distilled water with $5 \mathrm{ml}$ anthrone reagent).

\section{Calculation}

Concentration of sugar of unknown sample $=$ Concentration of known sample x Optical density of unknown sample/ Optical density of known sample.

2.6.4. Anti diabetic activity: (in vivo)

\section{Oral glucose tolerance test:}

On the first day of the experiment, a group of four mice were subjected to oral glucose tolerance test (OGTT). The glucose levels were measured using a complete blood glucose monitoring system. Then the results were observed.

\subsubsection{Intraperitoneal hypoglycemic activity}

Diabetes was induced by injecting alloxan $(150 \mathrm{mg} / \mathrm{kg}$ body weight). Intraperitoneal treatment done in all the mice according to the following procedure.

Experimental design: The mice were grouped into 4 groups, comprising of 4 mice in each group as follows:

Group I: Control mice

Normal mice with no diabetic inducers.

Group II: Alloxan induced diabetic mice.

Mice without treated by standard and plant extract as drugs. These are assumed as negative control.

Group III: Diabetic mice treated with Cocos nucifera endocarpic extract (300 $\mathrm{mg} / \mathrm{Kg}$ Body weight/day) in aqueous solution intravenously for 7 days.

Group IV: Diabetic mice treated with glibenclamide $(5 \mathrm{mg} / \mathrm{Kg}$ body weight/day) in aqueous solution intravenously for 7 days.

During the experimental period, body weight and blood glucose levels of all the mice were determined at regular intervals.

\section{Results and Discussion}

Plants have been used for the treatment of diseases throughout the world since in the beginning of civilization. It was popularly called as Ayurvedic and Unani system of medicine. The nutritional and pharmacological properties of the whole herb in its natural form as it has been traditionally used and may results from synergistic interactions of many different active phytochemicals.
Pharmacological activity and different parameters of plant extracts have been resulted as follows,

Table 1: Results of preliminary phytochemical tests

\begin{tabular}{|c|c|c|c|c|c|c|c|}
\hline S.no & Phytocompounds & \multicolumn{2}{c}{$\begin{array}{c}\text { Syzyium } \\
\text { cumini }\end{array}$} & \multicolumn{2}{|c|}{$\begin{array}{c}\text { Aegle } \\
\text { marmelos }\end{array}$} & \multicolumn{2}{c|}{$\begin{array}{c}\text { Cocos } \\
\text { nucifera }\end{array}$} \\
\hline 1. & Alkaloids & + & + & + & + & + & + \\
\hline 2. & Carbohydrates & - & - & - & - & - & - \\
\hline 3. & Saponins & + & + & + & + & + & + \\
\hline 4. & Phytosterols & + & + & + & + & + & + \\
\hline 5. & Phenols & - & + & + & + & + & + \\
\hline 6. & Tannins & - & - & + & + & + & + \\
\hline 7. & Flavanoids & - & + & + & + & + & + \\
\hline 8. & Diterpenes & + & + & + & + & + & + \\
\hline 9. & Steroid & - & - & - & - & + & - \\
\hline 10. & Terpenoid & - & - & + & + & - & + \\
\hline 11. & Pholabtannin & - & - & - & - & + & - \\
\hline 12. & Cycloglycosides & + & + & - & + & + & + \\
\hline 13. & Quinone & - & + & + & + & + & + \\
\hline 14. & Glycosides & - & - & - & - & - & + \\
\hline 15. & Anthroquinone & - & - & - & - & - & - \\
\hline 16. & Leucoanthocyanin & - & - & -+ & - & - & - \\
\hline 17. & Fatty acids & + & + & + & + & + & + \\
\hline 18. & Cardiac glycosides & - & - & + & + & + & + \\
\hline
\end{tabular}

\subsection{Preliminary phytochemical analysis}

The preliminary phytochemical screening tests for methanol and aqueous extracts were done with standard reagents mixture. The presence and absence of phyto compounds were assumed as results and are tabulated in table, 1.

\subsection{Paper chromotography}

Using standard formula $\mathrm{Rf}$ values were calculated and the compounds for respectable Rf values were tabulated in table 2 ,

Table 2: Results for thin layer chromotography

\begin{tabular}{|c|c|c|}
\hline S.No & Plant extracts & Retention factor [Rf value] \\
\hline 1. & S.cumini (water) & 0.84 \\
\hline 2. & S.cumini (methanol) & 0.50 \\
\hline 3. & A.marmelos (water) & 0.66 \\
\hline 4. & A.marmelos (methanol) & 0.88 \\
\hline 5. & C.nucifera (water) & 0.38 \\
\hline 6. & C.nucifera (methanol) & 0.46 \\
\hline
\end{tabular}

$\mathrm{Rf}$ value of the three plant extract is closely related to the following compounds,

$0.66=$ Terpenoid, $0.88=$ caffeine (alkaloid)

$0.84=$ closely related to Flavanoids, $0.50=$ Papaverine (alkaloid)

$0.38=$ closely related to Protopine and Strychnine (alkaloid), $0.46=$ Terpenoid

\subsection{HPLC analysis of Cocos nucifera extract:}

The HPLC chromatograms for an aqueous extract of Cocos nucifera is shown in table 3 ,

Table 3: Results for HPLC test

\begin{tabular}{|c|c|c|c|c|c|}
\hline S.no. & $\begin{array}{c}\text { Area } \\
{[\%]}\end{array}$ & Height & WO5 & Retention & Phyto compound \\
{$[\%]$} & {$[\mathrm{min}]$} & Time[min] & \\
\hline
\end{tabular}




\section{International Journal of Science and Research (IJSR) \\ ISSN (Online): 2319-7064}

Index Copernicus Value (2015): 78.96 | Impact Factor (2015): 6.391

\begin{tabular}{|l|c|c|c|c|c|}
\hline 1. & 30.3 & 52.0 & 0.13 & 1.983 & Stevioside \\
\hline 2. & 63.9 & 43.2 & 0.19 & 2.133 & Solanesol [terpenoid] \\
\hline 3. & 5.2 & 3.7 & 0.19 & 3.063 & Indole Alkaloids \\
\hline 4. & 0.6 & 1.1 & 0.11 & 6.297 & Quercetin [phenols] \\
\hline
\end{tabular}

Results for comparison of natural and chemical drugs was tabulated in table 9 ,

\subsection{Anti oxidant activity}

The result for analysis of antioxidant activity in Cocos nucifera were tabulated in table:7,

Table 7: Results for in vitro antidiabetic activity

\begin{tabular}{|c|c|c|c|}
\hline S.no & $\begin{array}{c}\text { Concentration } \\
(\mathrm{mg} / \mathrm{ml})\end{array}$ & $\begin{array}{c}\text { Scavenging of DPPH(\%) } \\
\text {-C.nucifera (water) }\end{array}$ & $\begin{array}{c}\text { Results in } \\
\text { Percentage }\end{array}$ \\
\hline 1. & DPPH Control & 0.762 & - \\
\hline 2. & 5 & 0.317 & $51.44 \%$ \\
\hline 3. & 10 & 0.306 & $59.81 \%$ \\
\hline 4. & 20 & 0.302 & $60.33 \%$ \\
\hline 5. & 40 & 0.301 & $60.49 \%$ \\
\hline 6. & 60 & 0.250 & $67.19 \%$ \\
\hline 7. & 80 & 0.246 & $68.50 \%$ \\
\hline 8. & 100 & 0.231 & $69.81 \%$ \\
\hline
\end{tabular}

\subsection{Antidiabetic activity (in vitro)}

All the concentration of the plant extracts contain sugar degrading capacity. Among these, aqueous extract of Cocos nucifera reduces sugar up to $76 \mathrm{mg} / \mathrm{ml}$ in day $\mathrm{V}$ and the results were tabulated in table 7 ,

\section{6 in vivo anti diabetic activity}

Results for in vivo antidiabetic activity in oral glucose tolerance test were tabulated in table 8 ,

Table 8: Oral glucose tolerance test

\begin{tabular}{|c|c|c|c|c|c|}
\hline \multirow[t]{2}{*}{$\mid \begin{array}{c}\text { Animal } \\
\text { body weight }\end{array}$} & \multirow[t]{2}{*}{$\begin{array}{l}\text { Drug and } \\
\text { treatment }\end{array}$} & \multirow{2}{*}{$\begin{array}{c}\text { Normal } \\
\text { blood } \\
\text { glucose } \\
\text { level } \\
\text { (before) } \\
\text { mg/dl }\end{array}$} & \multicolumn{3}{|c|}{$\begin{array}{l}\text { Blood glucose level } \\
\text { after drug } \\
\text { administration (in } \\
\text { min) } \mathrm{mg} / \mathrm{dl} \text {. }\end{array}$} \\
\hline & & & 30 & 60 & 90 \\
\hline $\begin{array}{l}\mathrm{H}-140 \\
\mathrm{~B}-120 \\
\mathrm{~T}-120 \\
\mathrm{C}-130\end{array}$ & $\begin{array}{l}\text { Control Tween } \\
80+\text { Glucose } \\
2 \mathrm{~g} / \mathrm{kg} \mathrm{p.o}\end{array}$ & 088 & 121 & 141 & 148 \\
\hline $\begin{array}{l}\text { H-100 } \\
\text { B-130 } \\
\text { T-120 } \\
\text { C-110 }\end{array}$ & $\begin{array}{c}\text { Glibenclamide } \\
600 \mu \mathrm{g} / \mathrm{kg} \mathrm{p.o}+ \\
\text { Glucose } 2 \mathrm{gm} / \mathrm{kg} \\
\text { p.o }\end{array}$ & 089 & 090 & 092 & 088 \\
\hline $\begin{array}{l}\text { H-120 } \\
\text { B-100 } \\
\text { T-110 } \\
\text { C-120 }\end{array}$ & $\begin{array}{c}\text { Sample } 200 \\
\mathrm{mg} / \mathrm{kg} \text { p.o }\end{array}$ & 088 & 091 & 095 & 094 \\
\hline
\end{tabular}

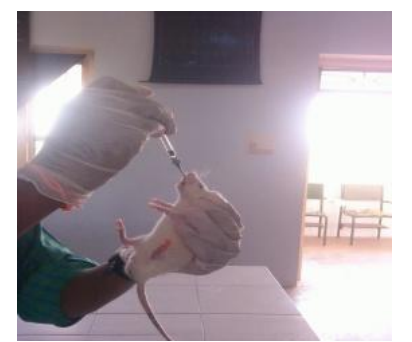

Figure 2: Oral glucose tolerance test

Table 9: Comparison of allopathy drug and Cocos nucifera extract in in vivo condition

\begin{tabular}{|c|c|c|c|c|c|}
\hline \multirow{3}{*}{$\begin{array}{l}\text { G. } \\
\text { No }\end{array}$} & \multirow{3}{*}{$\begin{array}{l}\text { Animal } \\
\text { body } \\
\text { weight } \\
\text { (gm) }\end{array}$} & \multirow{3}{*}{$\begin{array}{l}\text { Drug and } \\
\text { treatment }\end{array}$} & \multicolumn{3}{|c|}{ Blood glucose level } \\
\hline & & & \multirow{2}{*}{$\begin{array}{l}\text { Before } \\
\text { injecting } \\
\text { alloxan }\end{array}$} & \multirow{2}{*}{$\begin{array}{c}\text { After } 48 \\
\text { hrs of } \\
\text { alloxan } \\
\text { induction }\end{array}$} & $\begin{array}{c}\text { After drug } \\
\text { administration }\end{array}$ \\
\hline & & & & & $0-7$ days \\
\hline \multirow[t]{4}{*}{ I } & H-140 & \multirow[t]{4}{*}{ Control } & 74 & 75 & 65 \\
\hline & B-130 & & 75 & 78 & 64 \\
\hline & $\mathrm{T}-140$ & & 76 & 82 & 64 \\
\hline & $\mathrm{C}-110$ & & 72 & 89 & 77 \\
\hline \multirow[t]{4}{*}{$\overline{\text { II }}$} & $\mathrm{H}-140$ & \multirow{4}{*}{$\begin{array}{c}\text { Alloxan } \\
150 \mathrm{mg} / \mathrm{kg} \text { i.p }\end{array}$} & 78 & 254 & 356 \\
\hline & B-120 & & 77 & 252 & 362 \\
\hline & $\mathrm{T}-150$ & & 75 & 245 & 358 \\
\hline & $\mathrm{C}-110$ & & 73 & 302 & 408 \\
\hline \multirow[t]{6}{*}{ III } & $\mathrm{H}-150$ & Standard & 77 & 221 & 68 \\
\hline & B-130 & Glibenclambide & 76 & 246 & 67 \\
\hline & $\mathrm{T}-160$ & $600 \mu \mathrm{g} / \mathrm{kg}$ & 75 & 289 & 68 \\
\hline & $\mathrm{C}-120$ & i.p & 74 & 228 & 70 \\
\hline & & & & & 91 \\
\hline & & & & & 92 \\
\hline \multirow[t]{4}{*}{ IV } & $\mathrm{H}-140$ & \multirow{4}{*}{$\begin{array}{c}\text { Sample } \\
200 \mathrm{mg} / \mathrm{kg} \text {.p.o }\end{array}$} & 78 & 256 & 90 \\
\hline & B-150 & & 77 & 262 & 88 \\
\hline & $\mathrm{T}-130$ & & 74 & 323 & 91 \\
\hline & C-140 & & 79 & 354 & 92 \\
\hline
\end{tabular}

In conclusion, an attempt has been made to evaluate one of the medicinal plants that have attracted considerable global intrest in recent years. It is clearly found that the extract of cocos nucifera possess compounds with antidiabetic activity

From the study and with previous literature survey of [13],[14],[15], Obviously we conclude that the leaves of Syzyium cumini, Aegle marmelos and endocarpic membrane of Cocos nucifera is a good source which posses potent anti diabetic activity. There was a significant difference between methanol and aqueous plant extract. Consequently, the overall effects of these plant extracts cannot be fully duplicated with the isolated compounds or extracts. Because of its inherent botanical and biochemical complexity, plant extracts like bael, jambul and tender coconut had, so far be eluded as in modern science. The plant studies here can be seen as a potential source of useful drugs.

Anti diabetic activity in in vivo analysis, diabetic was induced by alloxan. It is then treated with standard drug and the plant extract. Decreased in hypoglycemic action takes place. The drugs which are given are glibenclamide and aqueous extract of endocarpic tender coconut. Moreover equal decreased in blood sugar level takes place,

Glibenclamide $=70 \mathrm{mg} / \mathrm{ml}$;

Cocos nucifera $=88 \mathrm{mg} / \mathrm{ml}$

The endocarps of Cocos nucifera are discarded as waste and it is considered as one of the major agro wastes of the tropical countries. Therefore our study will definitely open up a scope for future utilization of these agro wastes for 


\section{International Journal of Science and Research (IJSR) \\ ISSN (Online): 2319-7064 \\ Index Copernicus Value (2015): 78.96 | Impact Factor (2015): 6.391}

therapeutic purpose. This could be sure that the plant source were of less side effects. Soon it could reach for the treatment by the consumption of humans. Like wise [16] demonstrated the agrowaste of coconut protein has potent antidiabetic activity.

\section{References}

[1] Bolanle Iranloye, Gabriel Oludare, Makinde Olubiyi, 2013. Anti-diabetic and antioxidant effects of virgin coconut oil in alloxan induced diabetic male Sprague Dawley rats. Journal of Diabetes Mellitus . Vol.3, No.4, 221-226.

[2] Cristina C, D Olivia, S.Carmen, 2012. Plants and Natural Compounds with Antidiabetic Action. Notulae Botanicae Horti Agrobotanici Cluj-Napoca. 40(1):314325

[3] Emojevwe V, and E Jeroh, 2012. Anti diabetic effects of the cocos nucifera (coconut) husk extract. Journal of Medical and Applied Bioscience. Volume 4.

[4] Ganesh N, K.Susheel Dubey, S Piush, S Nitin 2011. Medicinal Values of Bael

[5] Dyana P, and G Kanchana, 2012. Preliminary phytochemical screening of cocos nucifera 1. flowers. International journal of current pharmaceutical research. vol 4: 60-63.

[6] Himesh S, N Govind, S Patel, K Mishra and AK Singhai, 2011. Pharmacognostic Studies of the Leaves of Syzygium cumini. International Journal of Research in Pharmaceutical and Biomedical Sciences. Vol 2 (2), 2229-3701.

[7] H.Mohammad, M. Ratan, 2012. Evaluation of antidiabetic phytochemicals in Syzygium cumini. Journal of Applied Pharmaceutical Science. Vol. 2(10): pp 094-098.

[8] Islam R, M Hossain, M R Karim, O I Joarder, 1995. Regeneration of Aegle marmelos (L.) Corr., plantlets in vitro from callus cultures of embryonic tissues. Curr Sci. 69, 494-5.

[9] Patel A, D Garach, M Chakraborty, V Kamath jagdish, 2012. Aegle marmelos, a therapeutic boon for human health. International journal of research in plants. Vol3(2) : 159- 163.

[10] Rajeev, KJ Nitesh, G.Varadaraj Bhat, J Hitesh, 2011. Antioxidant \& Antimicrobial Activities of Cocos Nucifera (Arecaceae) Endocarp Extracts. Indo Global Journal of Pharmaceutical Sciences, 2011; 1(4): 354 361.

[11] Saranya, S Pradeepe, S Subramani, 2014. Bio chemical evaluation of Antidiabetic activity of Cocos nucifera flowers in STZ induced diabetic rats. International journal of pharmacological science review and research. 26(1): $67-75$.

[12] Verma D, S Rohan, R Gavankar and S Bhalerao, 2013.Phyto chemical constituents of different medicinal plants. International Research Journal of Biological Science. Vol. 2(7), 50-54.

[13] Chaudary B, and K Mukhopadhyay, 2012. Syzyium cumini : a potential source of nutraceuticals. International journal of pharmacacy and biological sciences. 2 : 26-53.

[14] Komala s, M Mohammed, V Ruby and K P Sampath kumar, 2011. Antibacterial potential of root and bark of cocos nucifera against isolated urinary tract infections causing pathogens. International journal of pharma and bio sciences. 2:490-500.

[15] Sevugan A, K Subramaniam, K Balamuthu, B Abdul, A Mohammed abdulkadar, V Mandali, 2008. Antidiabetic activity of leaf and callus extracts of Aegle marmelos in rabbit. Science asia. 34:317-321.

[16] Swee Ngin Tan, Jean Wan Hong Yong, and Liya Ge Analysis of different classes of phytoharmones in coconut water using High Performance liquid Chromotography and liquid chromatography tandem mass spectrometry after solid phase extraction. Analytica chimica acta. 61 0: 274-281. 